\title{
The Epistemic Relevance of the Virtue of Justice"
}

\section{Stewart Clem}

Aquinas Institute of Theology, 23 S. Spring Ave., St. Louis, MO 63108 USA

clem@ai.edu

Abstract Recent literature on the relationship between knowledge and justice has tended to focus exclusively on the social and ethical dimensions of this relationship (e.g. social injustices related to knowledge and power, etc.). For the purposes of this article, I am interested in examining the virtue of justice and its effects on the cognitive faculties of its possessor (and, correspondingly, the effects of the vice of injustice). Drawing upon Thomas Aquinas's account of the virtue of justice, I argue that in certain cases justice can be a criterion of epistemic evaluation and that it deserves more attention than it has been given among virtue epistemologists. More precisely, the virtue of justice may become a criterion of epistemic evaluation in cases when a belief is formed on the basis of testimony. It would seem that there are cases when A's assent to proposition $p$ is something that is owed to B on the basis of B's testimony; or there may be instances when A is culpable for declining to let B's testimony have any effect on A's belief. I briefly sketch four distinct scenarios in which this bears out.

Keywords Justice • Virtue Epistemology • Testimony • Thomas Aquinas

\section{Introduction}

Recent literature on the relationship between knowledge and justice has tended to focus exclusively on the social and ethical dimensions of this relationship (e.g. social injustices related to knowledge and power, etc.). ${ }^{\mathrm{I}}$ For the purposes of this article, I am interested in examining the virtue of justice and its effects on the cognitive faculties of its possessor (and, correspondingly, the effects of the vice of injustice). ${ }^{2}$ I shall argue that, in certain cases, justice can be a criterion of epistemic evaluation ${ }^{3}$ and that it deserves more attention than it has been given among virtue epistemologists. ${ }^{4}$

\footnotetext{
* This article was originally published in Philosophia 4I (20I3): 30I-3II. The final publication is available at Springer via $\underline{\mathrm{http}} / / / \mathrm{dx}$.doi.org/IO.I007/sII406-0I3-9433-6. Please consult published version before citing or quoting. I owe much to criticisms and suggestions from Paul Griffiths, Reinhard Hütter, and an anonymous Philosophia reviewer on an earlier draft of this article. I am also grateful to participants at the 20I2 Society of Christian Philosophers Midwest Conference who offered insightful questions and feedback when a version of this paper was presented.
} 
The virtue of justice, according to Aristotelian and Thomistic models, is not counted

among the intellectual virtues; rather, it is found among the list of moral virtues. For Aquinas, justice perfects the rational appetite, or the will, whereas moderation and courage perfect the sensitive appetite. 5 Justice, then, is unique among the cardinal virtues in that it is not concerned with the affective state of the moral agent, but rather with outward operations in which something is due to another. Prima facie, it would seem that justice has no immediate place in epistemic evaluation, even on the most robust varieties of virtue epistemology. And yet, while it would be wildly anachronistic to construe Aquinas as a sort of virtue

\footnotetext{
${ }^{I}$ For a recent, systematic treatment, see Fricker 2003 and 2007. My treatment of epistemic justice and injustice differs from Fricker's in the sense that, where she is concerned primarily with the transmission of knowledge, I am concerned in this article with the reception of it. Her project is more concerned with broadening epistemology's range of analysis by describing the harms of epistemic injustice; I am more concerned with the application of the virtue of justice to more traditional concerns of epistemology. Our projects are complementary but distinct. Although the case of simple prejudice (see below) comes close to her account of "testimonial injustice", in my example the cognitive defect of the agent lies not in some prejudice against another person on account of race, gender, or class (as in most of Fricker's examples), but rather in the agent's willing something so strongly and unreflectively such that it precludes his belief from arriving at the level of knowledge. The kinds of prejudices which concern Fricker do become relevant in the case of basic testimonial authority (see below), but, again, they are applied to different ends.
}

${ }^{2}$ For an illuminating analysis of justice as a self-regarding virtue, see Bloomfield 20II. Bloomfield, however, does not discuss the epistemological implications of justice, nor does he engage Aquinas's thought. Kawall addresses the concept of other-regarding epistemic virtues in Kawall 2002, but my account differs from his because, although justice is a mostly other-regarding virtue, in my account it is being applied reflexively to the agent for the purpose of assessing her own cognitive formation.

3 By "criteria of epistemic evaluation," I mean something similar to William Alston's description of a plurality of factors which can lead to various epistemic desiderata and in which "each item in the plurality deserves some attention as a possible contributor to a positive epistemic status of beliefs" (Alston 2005, p. 39).

${ }^{4}$ Roberts and Wood, for example, analyze a remarkably wide range of virtues, yet justice is only used as an example of why one should not mislead others with deception (Roberts and Wood 2007, p. 137). There is no mention of the role of justice in the reception of knowledge.

${ }^{5}$ For Aquinas, virtues are distinguished according to the powers of the soul they perfect, where 'power' simply refers to an ability to bring about action: "In the rational part [of the soul] are found (i) a power of desire, which is called the will, and (ii) a power of apprehension, which is called reason. That is why there are two cardinal virtues in the rational part, practical wisdom, which belongs to reason, and justice, which belongs to the will" (On the Virtues in General, a. 12, ad. 25 in Aquinas 2005). Furthermore, "For each domain there ought to be a cardinal virtue that deals with whatever is most important in it. There are, however, virtues that deal with other elements of the matter, and they are called secondary, or additional, virtues. [...] [I]n actions that relate to those external things that we use for living, the first and most important thing is that everyone is given what is his due. Justice ensures that" (Ibid., a. I2, ad. 26). 
epistemologist, ${ }^{6}$ it is nevertheless true that, on his account, if the will is lacking its proper

virtue, this will have a deleterious effect on the agent's intellect and can thus result in a

malfunction in her cognitive processes. ${ }^{7}$ The virtue that is lacking in such a case is the virtue of justice. Even if one does not accept Aquinas's anthropology wholesale, his account of justice is fertile with suggestions for contemporary virtue epistemology.

\section{Aquinas's Account of Justice in the Context of Virtue Epistemology}

Thus, I begin with two presuppositions: With Aquinas, I assume that (I) justice is a virtue that perfects the will (so that it inclines toward goods that are perceived by the intellect).

Furthermore, (2) According to nearly all models of virtue epistemology, knowledge is true belief which results from the exercise of an agent's epistemic virtue(s). ${ }^{8}$ Of course, one of the central disagreements among the various schools of virtue epistemology is precisely over what

\footnotetext{
${ }^{6}$ Thomas Hibbs persuasively demonstrates that none of the modern labels 'internalist', 'externalist', or 'virtue epistemology' neatly maps onto Aquinas's theory of knowledge in Hibbs 1999.

${ }^{7}$ In making this qualification, I do not mean to suggest that Aquinas is oblivious to the relationship between knowledge and justice. He classifies truth (or truthfulness) as a virtue annexed to justice: "Now the virtue of truth has two things in common with justice. On the first place it is directed to another, since the manifestation, which we have stated to be an act of truth, is directed to another, inasmuch as one person manifests to another the things that concern himself. On the second place, justice sets up a certain equality between things, and this the virtue of truth does also, for it equals signs to the things which concern man himself. Nevertheless it falls short of the proper aspect of justice, as to the notion of debt: for this virtue does not regard legal debt, which justice considers, but rather the moral debt, in so far as, out of equity, one man owes another a manifestation of the truth. Therefore truth is a part of justice, being annexed thereto as a secondary virtue to its principal" (ST II-II, q. I09, a. 3, in Aquinas 198I). This article is an exploration of the reverse relationship, namely, when the reception of truth is what is owed to another, rather than the manifestation of it.

${ }^{8}$ I use the somewhat vague term "epistemic" virtue intentionally, since the dispute between internalist virtue epistemologists and externalist epistemologists reflects a disagreement on whether the epistemically relevant virtues are states of character or faculties (for a helpful summary of this difficulty, see Moros and Umbers 2004). I take the following as paradigmatic of internalist-leaning virtue epistemologists: "Knowledge is a state of true belief arising out of acts of intellectual virtue" (Zagzebski 1996, p. 27I). And I take the following as paradigmatic of externalist-leaning virtue epistemologists: "A belief $p$ has positive epistemic status for a person S just in case S's believing that $p$ results from stable and reliable dispositions that make up S's cognitive character" (Greco 1999, $p$. 19). Greco has refined his articulation of knowledge to be understood as "a kind of success from ability" (Greco 20IO, p. I), or, in other words, credit-worthy true belief, but his overall model remains broadly externalist-leaning.
} 
in fact constitutes a virtue and what kinds of virtues are relevant for epistemic evaluation. ${ }^{9}$ I shall bracket this question for the time being and turn to what Aquinas says about virtue (specifically the virtue of justice), and allow him to speak on his own terms. I shall likewise leave the question open as to what kind(s) of virtue epistemology might be aided by this account. $^{10}$

For Aquinas, virtues are distinguished not only by the kinds of actions they produce, but also according to the powers of the soul that they perfect." Justice, then, perfects the will and is concerned with rectitude in external relations among people ${ }^{\mathrm{I} 2}$ (ST I-II, q. 56, a. 6, in Aquinas $198 \mathrm{I}) .{ }^{13} \mathrm{He}$ explains that in operations in which there is an element of something due or undue to another, there must be some kind of power, or ability, to regulate the operations in themselves (ST I-II, q. 60, a. 2). "Justice," he writes, "is a habit whereby a man renders to each one his due by a constant and perpetual will" (ST II-II, q. 58 , a. I). ${ }^{14}$ Thus, the external effect of an act of justice is that it results in each person in any given scenario receiving his or her due; its internal effect is that the will of the person performing the action is perfected, or habituated to achieve some good toward which it is inclined. There is a remarkable asymmetry in Aquinas's treatment of these two aspects in his Summa Theologiae. His description of justice as a disposition of the will (the internal aspect) is confined to a few

\footnotetext{
${ }^{9}$ For examples of an account that attempts to unite faculties and character traits as both contributing in different ways to the acquisition of true beliefs, see Baehr 2006 and Lepock 20II.

${ }^{\text {Io }}$ For a helpful survey of some recent varieties of virtue epistemology, see Baehr 2008.

II See fn. 5 above.

${ }^{12}$ Cf. also Aquinas's Commentary on Aristotle's Nicomachean Ethics, Bk. V, Lecture I, 889 (in Aquinas I993).

${ }^{13}$ All references to the Summa Theologiae are from Aquinas 198I. Subsequent references to the Summa will be cited using the traditional notation.

I4 “[I] ustitia est habitus secundum quem aliquis constanti et perpetua voluntate ius suum unicuique tribuit." All Latin quotations of Aquinas's works are from the Leonine edition found in Aquinas 2012.
} 
passing references, yet the Secunda Secundae treats question after question regarding the external aspect (ST II-II, qq.57-I22). Nevertheless, both aspects hang together, and for our purposes, it is crucial that we maintain the integrity of this duality.

It is also important to remember that Aquinas understands the will as the "rational appetite." In Disputed Questions on the Virtues, he explains, "the will naturally desires whatever is good according to reason, just as the sensual part desires whatever is pleasurable according to the senses" (On the Virtues in General, a. 5, ad. I, in Aquinas 2005). Furthermore, it "inclines not only towards the ultimate end, but also to any good that reason presents to it" (Ibid., ad. 2). Aquinas is clear that the will does not require any virtues in order to do this. If the intellect presents something good to the will as good simpliciter, then the will inclines toward it..$^{15}$ That is its natural function as a human faculty. Yet, this only occurs in cases when the perceived good is on the will's "own level," as Aquinas puts it. He writes,

However, [the will] does need a virtuous disposition to aim at a good that surpasses the level of its own capacity. Now a thing's desire aims at its own distinctive good. We can, then, say that a good can exceed the level of the will in two ways: (i) in terms of the species, (ii) in terms of the individual. ${ }^{16}$

The first way is not relevant for our purposes, ${ }^{17}$ but the second way reveals a sense in which Aquinas is beginning to approach our epistemological concerns. He continues,

The second happens when someone seeks a good that belongs to someone else, but without the will's being drawn beyond the boundaries of human good. In this case, justice is needed to complete the will, along with all the virtues that

\footnotetext{
${ }^{15}$ In De Veritate, q. 22, a. 5 (in Aquinas 1994), among other places, Aquinas explains that the will necessarily inclines toward happiness as its last end, but it inclines toward specific means voluntarily, inasmuch as it perceives them (through the intellect) to be means to that last end. Thus, the will is indeterminate.

${ }^{16}$ On the Virtues in General, a. 5, Reply, in Aquinas 2005. "[S]ed ad bonum quod transcendit proportionem potentiae, indiget habitu virtutis. Cum autem uniuscuiusque appetitus tendat in proprium bonum appetentis; dupliciter aliquod bonum potest excedere voluntatis proportionem. Uno modo ratione speciei; alio modo ratione individui."

${ }^{17}$ Although, in light of the concerns of this article and what Aquinas says about the virtue of religio (a virtue annexed to justice; see ST II-II, qq. 8I-IOO), it does raise some interesting questions about what is due to God in regard to testimony and about what might constitute testimony from God.
} 
are directed at other people, for example liberality. For justice is another's good, as Aristotle says [NE 5.I.I7, II3Oa4]. ${ }^{18}$

Certainly, Aquinas is not concerned here with epistemological questions. Even when he does address epistemological questions, his concerns are often not our concerns (and vice versa). Yet, it is conceivable that there may be instances when "what is due to another" is of epistemic relevance. I am thinking here specifically of the function of testimony in belief formation, or, more broadly, when reliance on others is an integral component of belief formation (which turns out to be quite often). Specifically, the virtue of justice may become a criterion of epistemic evaluation in cases when a belief is formed on the basis of testimony (hereafter I am using 'testimony' in the inclusive sense to encompass "reliance on others"). It would seem that there are cases when A's assent to proposition $p$ is something that is owed to B on the basis of B's testimony; or there may be instances when A is culpable for declining to let B's testimony have any effect on A's belief. Put another way, the virtue of justice, when properly habituated in a person, disposes that person to give assent to testimony that ought to be assented to. I shall briefly sketch four distinct types of scenarios in which this bears out: I) simple prejudice, 2) the epistemic renegade, 3) volitional obstinacy, and 4) basic testimonial authority.

\section{The Case of Simple Prejudice}

First, the case of simple prejudice. Suppose the following: Tom has murdered his next-door neighbor in broad daylight and with no apparent motive, and he is subsequently accused of murder. Frank is a jury member during the court case. Frank has yet to hear the arguments of either the defense or the prosecution, but he is predisposed to believe that Tom is guilty

\footnotetext{
${ }^{18}$ On the Virtues in General, a. 5, Reply, in Aquinas 2005. "Ratione autem individui, hoc modo quod aliquis quaerat id quod est alterius bonum, licet voluntas extra limites boni humani non feratur; et sic voluntatem perficit iustitia, et omnes virtutes in aliud tendentes, ut liberalitas, et alia huiusmodi. Nam iustitia est alterius bonum, ut philosophus dicit in V Ethic."
} 
because he is shocked that an innocent person could be murdered in such a way, and, subconsciously, he would rather walk away from the trial knowing that someone was punished for the crime rather than leaving the case cold. When the trial comes, Frank listens to a number of witnesses. Surprisingly, the witnesses for the prosecution give an account that is woefully underwhelming. Not only do their statements conflict with each other's, even their individual accounts are riddled with inconsistencies. They are only united in their assertion that Tom is guilty. The witnesses for the defense, however, provide evidence and make strong, consistent claims that if true, would make it seem virtually impossible that Tom could have committed the murder. Frank is unmoved. He overlooks these features and simply gives his assent to the first witnesses' claim that Tom is guilty.

Using Aquinas's terminology, we could describe the situation in the following way. Frank's will is motivated by the perceived good of a world in which no crime is left unpunished. This is the kind of world that Frank would want to live in, and his will is inclined accordingly. In the instance of the court case, however, he is faced with a scenario which requires that his will should "aim at a good that surpasses the level of its own capacity" (Ibid.). That is, in this specific instance, something is due to the witnesses who come before the jury, namely, that the jury members give or withhold their assent to the testimonies they hear from the witnesses on the merits of the testimonies themselves. ${ }^{19}$ Since this is a good that belongs to someone else, Frank must possess a virtue that would enable his intellect to give assent on these grounds. That virtue, of course, is justice. What is especially noteworthy is the epistemic

\footnotetext{
${ }^{19} \mathrm{An}$ anonymous reviewer suggests that perhaps assent is due, not to the testimony, but to the person giving the testimony, i.e. on the merits of the testifier rather than the merits of the testimony. The difficulty with articulating the scenario in this way is that the jury members presumably do not know anything about the persons giving the testimony and thus have no grounds for assenting to their testimonies based some sort of prior reputation. All the jury members have to go on is the cogency and plausibility of the testimonies they hear, and thus what is due to the testifiers is that assent be given to their testimonies without any sort of bias. I believe the sort of deference to persons that the reviewer has in mind will become more relevant in the case of the epistemic renegade (below).
} 
relevance of Frank's virtue (or lack thereof). His will was inclined toward a perceived good one with which many people would sympathize - yet, had he possessed the virtue of justice, his will would have inclined him to withhold his assent to the belief that Tom was guilty. Instead, he maintained a true belief (i.e. that Tom was guilty) which fell short of actual knowledge.

\section{The Case of the Epistemic Renegade}

Second, the case of the epistemic renegade. I am borrowing the phrase from Bryan Frances, who uses it to describe the apparent irresponsibility of philosophers who "often find themselves in disagreement with contemporary philosophers they know full well to be their epistemic superiors on topics relevant to the disagreement" (Frances 20IO, p. 419). It is relevant to this article in an analogous way. We can think of instances where it might be the case that, even if the same argument is used by two different sources to support $p$, a person may be entitled to believe $\sim p$ when the argument comes from one source but not when it comes from another source..$^{20}$ For example, say that Joe believes that the Apollo II moon landing of 1969 was a hoax that was fabricated by the U.S. government in a Hollywood studio. He believes this because someone once presented to him a number of features of the moon landing that simply could not have occurred the way they were reported (by appealing to laws of gravity, light reflection, etc.). Sometime later, Joe stumbles upon the website of an amateur NASA enthusiast who presents a compelling case for the claim that the moon landing was real. The arguments he encounters raise many doubts in his mind about his current belief, but he recognizes his own incompetency to assess fully the details of the arguments. In other words, the overall counter-argument does not rise to the level of a defeater for his belief. Let us say

\footnotetext{
${ }^{20}$ This assumes that, whatever the criterion that distinguishes knowledge from mere belief, it is something that comes in degrees and crosses the threshold of knowledge at a certain point.
} 
that it approaches the precipice of being a defeater, while falling just shy of it. He sees no reason to abandon his belief that the moon landing was a hoax, so he continues to maintain that belief. While most people would agree that his belief happens to be false, it does not seem that Joe is culpable for maintaining it.

But suppose that Joe brings the challenge to his friend, Harold, who is a professor of physics. Not only does Harold have superior knowledge on scientific matters, there have also been several occasions in the past when Harold has corrected Joe's faulty beliefs about the world through compelling demonstrations. In this instance, Harold defends the authenticity of the Apollo II landing using the exact same arguments that were utilized by the author of the anonymous website that Joe stumbled upon. It would seem that the criteria of Joe's epistemic evaluation are identical in both instances, with one important difference: in the latter instance, the argument is coming from Harold. We must remember that Harold is someone who has repeatedly and reliably convinced Joe of some truth $p$ when $p$ pertains to scientific matters. Harold's superior knowledge, combined with his consistent track record, has made him a trustworthy source for Joe. Thus, we have:

I) the counter-argument to Joe's belief that the moon landing was a hoax, which Joe has already found persuasive to the point of being a near defeater for his original belief

and

2) the testimony of Harold, whom Joe has no reason to doubt except for the fact he wants to maintain his original belief

thus,

3) Joe must either accept that (a) the moon landing was a hoax or (b) that it was not. $^{2 \mathrm{I}}$

\footnotetext{
${ }^{21}$ Of course, there is also the possibility (c) he is uncertain. The case of (c) is interesting, because in many scenarios, it will be difficult to determine whether an agent's transition from belief $p$ to an uncertainty about $p$ reveals something about the agent's possession of the virtue of justice. If the scenario is one in which $p$ is a deeply seated belief which grounds much of how the agent understands the world, then it does not seem that the agent's refusal to believe $\sim p$ is a violation of justice, even if it entails the rejection of a Harold-like testimony.
} 
If he accepts (b), it would seem that this belief is a good candidate for knowledge on most varieties of virtue epistemology. If so, then, in this case the aspect of the belief that transformed it into knowledge (as opposed to mere belief) is the fact that it is a true belief to which Joe gave his assent based on Harold's testimony. ${ }^{22}$ And because Harold is Joe's epistemic superior who has a reliable history, this may be a situation in which Joe's giving of his assent to Harold is giving what is due to him. It is an exercise of justice. If Joe accepts (a), however, it would seem that he is a sort of epistemic renegade who is culpable for maintaining his belief. ${ }^{23}$

\section{The Case of Volitional Obstinacy}

It should be noted that this anti-renegade strategy does not entail that epistemic superiors are never in a position to be challenged by their epistemic inferiors. One can easily imagine scenarios in which the reverse holds true. This brings us to the third case: volitional obstinacy. For this case, I have in mind certain features that bring the role of the will to forefront. Imagine a brilliant mathematician, Jane, who is explaining one of her pet theories to a group of students. As she is giving a proof, one of the students catches an error and brings it to her attention. The error is such that it puts the entire theory in jeopardy, and she becomes

\footnotetext{
${ }^{22}$ If we can assume that Joe's reasons for holding his belief are so thin that in scenario (b) the weight of Harold's testimony renders them obsolete, then my analysis of this scenario is in accord with Lackey's account of testimonial knowledge: "For every speaker $S$ and hearer $H, H$ comes to know that $p$ via $S$ 's statement that $p$ only if (i) $S$ 's statement that $p$ is appropriately connected with the fact that $p$; and (ii) $H$ has no defeaters indicating the contrary" (Lackey 1999, p. 490).

${ }^{23}$ I grant that Harold's explanation in this example would not fall under 'testimony' in the narrow sense. Clearly it falls somewhere between basic perceptual knowledge and straightforward testimony (i.e. a report). Any instance in which one requires a teacher to explain a truth that lies beyond the grasp of that person's unaided cognitive abilities is of this sort. It describes most people's understanding of common scientific theories (gravity, evolution, etc.). Nevertheless, such instances are examples of knowledge which requires "reliance on others," which is why I have been using 'testimony' in the inclusive sense. Robert Audi draws a helpful distinction in his grammar of testimony between 'propositional telling' and 'imperative telling' that is relevant here (Audi 2006, pp. 25-26).
} 
infuriated with the student. Rather than acknowledge the error, she castigates the student and proceeds with the demonstration. It is not simply the case that she is embarrassed and does not want to admit her mistake. Rather, she is so personally invested in this theory that her judgment is obscured and she truly does not believe that any error has been committed.

Again using Aquinas's terminology, we could say that Jane's will is inclined toward the perceived good of producing mathematical theories that will provide a deep sense of satisfaction as well as make beneficial contributions to her field. She may also possess other concomitant desires, such as job security, notoriety, etc., which may not be incompatible with the former desires per se. When the student pointed out the error in her theory, however, she was faced with the obligation of giving the student something that was due to him, namely a response that corresponds to whether his input was correct or not. To refuse to do so was not only an act of injustice against the student; the virtue of justice that was lacking in Jane's response had an effect on her will such that it led to her maintaining a false belief (i.e. that her theory was sound). Her will was forced to arbitrate between two sets of desires which, while compatible in principle, came into conflict when the student's correction appeared to present them as incompatible in that moment.

In this example it is especially important to note that, according to a Thomistic grammar, it was Jane's will and not her intellect that was the primary actor in maintaining the false belief after the point of the student's correction. Accordingly, the virtue of justice becomes the most salient virtue in this scenario. In his discussion of justice, Aquinas displays a keen awareness of the nexus created by reason, truth, and will. He anticipates the objection that the virtue of justice must not reside in the will since justice discerns the truth of what is due to another, which would seem to be a purely intellectual activity. In the voice of the objector, "It would seem that justice is not in the will as its subject. For justice is sometimes 
called truth. But truth is not in the will, but in the intellect. Therefore justice is not in the will as its subject" (ST II-II, q. 58, a. 4, obj. I). Aquinas responds by clarifying, "Since the will is the rational appetite, when the rectitude of the reason which is called truth is imprinted on the will on account of its nighness to the reason, this imprint retains the name of truth; and hence it is that justice sometimes goes by the name of truth" (ST II-II, q. 58, a. 4, ad. I). This is not mere semantics. The point is that since justice produces the act of giving what is due to someone (and action is driven by appetite rather than cognitive faculties), it follows that justice resides in the will, which is the rational appetite. The corollary is that since "pure" appetite (or what Aquinas calls the "sensitive appetite") is not capable of discerning relations among things, which is a necessary feature of justice, it again follows that justice resides in the will, which is the rational appetite. ${ }^{24}$

\section{The Case of Basic Testimonial Authority}

Fourth, the case of basic testimonial authority. Imagine the following: Julie is visiting the Museum of Modern Art in New York for the first time. She has heard that Marc Chagall's painting, I and the Village, is there, and she wishes to see it. When she first arrives, she picks up some of the museum's literature to figure out where the painting is, but she is quickly

\footnotetext{
24 "I answer that, The subject of a virtue is the power whose act that virtue aims at rectifying. Now justice does not aim at directing an act of the cognitive power, for we are not said to be just through knowing something aright. Hence the subject of justice is not the intellect or reason which is a cognitive power. But since we are said to be just through doing something aright, and because the proximate principle of action is the appetitive power, justice must needs be in some appetitive power as its subject. Now the appetite is twofold; namely, the will which is in the reason and the sensitive appetite which follows on sensitive apprehension, and is divided into the irascible and the concupiscible, as stated in I, 8I, 2. Again the act of rendering his due to each man cannot proceed from the sensitive appetite, because sensitive apprehension does not go so far as to be able to consider the relation of one thing to another; but this is proper to the reason. Therefore justice cannot be in the irascible or concupiscible as its subject, but only in the will: hence the Philosopher (Ethic. v, I) defines justice by an act of the will, as may be seen above (Article I)" (ST II-II, q. 58, a. 4). Although Aquinas seems to suggest that justice is irrelevant to knowledge, he is simply making the point that the virtue of justice is not directly tied to any cognitive power. He certainly denies that justice is a necessary and sufficient condition for knowledge, but this comports with my more modest claim that in some cases justice can positively contribute to the wider process of belief formation and is thus an epistemically relevant virtue.
} 
overwhelmed. She looks around and notices a museum employee sitting behind a desk with a large sign above that reads "information". Julie approaches the employee and asks where I and the Village is located. The painting is one of the museum's more well-known pieces, and he quickly replies that it is located on the second floor in gallery I46. She takes him at his word and successfully finds the painting. ${ }^{25}$

It may not seem that the exchange between Julie and the MoMA employee in this scenario is a matter of justice. Suppose, however, that the employee is a racial minority and that Julie harbors a strong prejudice against minorities. Thus, rather than forming the belief " $I$ and the Village is located on the second floor," she withholds from forming the belief and decides to ask someone else where the painting is located. In the original scenario, she trusts the employee based on his status as a representative of the museum, the clearly designated "information" desk, the confidence of his reply, etc. He is an authority in this situation, and Julie's deference to his authority causes her to trust his answer, which leads to the formation of a true belief. ${ }^{26}$ It would seem that her belief meets the conditions for knowledge. Yet, if she were to disregard his answer because of her deep-seated prejudice, it would not only be an act of injustice against the employee ${ }^{27}$ but would also prevent her from possessing a true belief that she would otherwise have. Her failure to give the employee what was due to him was commensurate with her failure to arrive at the knowledge of the painting's location.

\footnotetext{
${ }^{25}$ This is a variation of the "Chicago visitor" example in Lackey 2007 and 2009. The most significant difference is that in my example the person being consulted is not a random passerby, but a clearly designated authority figure. This important detail is central to my analysis of the scenario.

${ }^{26}$ Although Zagzebski is primarily concerned with the notion of self-trust in Zagzebski 20I2, her articulation of epistemic trust in that essay is also relevant here. I would slightly modify her claim that "many of the intellectual virtues either restrain or enhance epistemic trust" (20) to include moral virtues as well, since justice is not typically classified as an intellectual virtue.

${ }^{27}$ Aquinas would classify this as the vice of "respect of persons", which is a vice opposed to justice (n.b. "respect" is here meant to refer to unjust preferential treatment). He explains, "Respect of persons is opposed to distributive justice. For the equality of distributive justice consists in allotting various things to various persons in proportion to their personal dignity" (ST II-II, q. 63, a. I).
} 
If Julie's failure to arrive at knowledge (in the case of prejudice) is an act of injustice, then it seems that her belief formation in the first scenario is an act of justice, even if only in a thin sense. ${ }^{28}$ Because her belief was formed on the basis of the testimony of someone who is in a basic position of authority (i.e. a representative of the museum who possesses knowledge of the museum's pieces), she gave him what was due by assenting to his statement that the painting is located on the second floor. While she may not be morally praiseworthy in a strong sense, her belief is at least attributable to her in a way that is distinct from non-testimonial belief formation. ${ }^{29}$ Moreover, to accept the testimony of someone who is clearly in a position of epistemic authority is to exhibit what Aquinas would call "rectitude of the will" (ST II-II, q. 58 , a. 4 , s.c.), which directs a person to render what is due to another.

\section{Conclusion: Justice as a Criterion of Epistemic Evaluation}

In this article, I have attempted to draw upon the self-regarding aspect of Aquinas's account of justice to demonstrate that it can be an epistemically relevant virtue. While Aquinas states that justice is always towards another (ST II-II, q. 58, a. 2), this is still compatible with my argument, since all of my examples involve testimony and transmission of knowledge between humans. Thus, while it is still true that there is always an other-regarding aspect to justice, my account demonstrates that there may be instances that also manifest a selfregarding aspect, and in such instances the virtue of justice becomes epistemically relevant. Perhaps these cases illustrate the point, articulated by Jason Baehr, that virtue reliabilists

\footnotetext{
${ }^{28}$ Aquinas acknowledges that "justice is first of all and more commonly exercised in voluntary interchanges of things, such as buying and selling, wherein those expressions are properly employed," yet he goes on to state that "they are transferred to all other matters of justice. The same applies to the rendering to each one of what is his own" (ST II-II, q. 58, a. II, ad. 3). Thus he concedes that "it belongs to justice not only to distribute things duly, but also to repress injurious actions, such as murder, adultery and so forth" (ST II-II, q. 58, a. II, obj. 3), and we might add to that list "acts of prejudice".

${ }^{29}$ I am drawing upon Wayne Riggs's helpful distinction between "praiseworthiness" and "attributability", which he utilizes in his response to Lackey in Riggs 2009.
} 
should not neglect so-called "trait-virtues" (such as justice), because they are in fact necessary to explain certain cases of knowledge..$^{30} \mathrm{It}$ is in Aquinas's account in particular, with its description of the will's role in bringing about what is due to another, that the relevance of a trait-virtue such as justice becomes most apparent.

As these four cases illustrate, when the internal (or self-regarding) aspect of the virtue of justice is analyzed alongside the external (or other-regarding) aspect in cases involving the transmission of knowledge through testimony, it is possible for justice to become a criterion of epistemic evaluation. Aquinas's account of the virtues allows us to see ways in which this might be so. I also suspect that there are other types of scenarios to which my analysis might apply, beyond the four that I have given in this article. ${ }^{3 \mathrm{I}}$ The answer, then, to the question posed in the Summa, "Where is justice?" is twofold. Aquinas's answer is simply "in the will." But secondly, as I have proposed, it also belongs among the list of epistemic virtues that should be of concern to epistemologists.

\footnotetext{
${ }^{30}$ Baehr argues that "responsibilist character virtues" such as those described by internalist-driven models of virtue epistemology should "satisfy virtue reliabilists' formal conditions for an intellectual virtue, and that consequently virtue reliabilists must include these traits in their repertoire of intellectual virtues. Indeed, failure to do so leaves virtue reliabilists unable to account for some of the most valued kinds or instances of knowledge" (Baehr 2006, p. 194).

${ }^{31}$ For example, the case of the epistemic egoist (see Zagzebski 2007). While there is some overlap between the egoist and the renegade, the two are distinct. It is true that, in the event that an epistemic superior argues for $p$ (suppose that $p$ is a claim about some event that occurred in the past), neither the egoist nor the renegade will accept $p$. The renegade rejects $p$ on the grounds of a firmly held conviction that $\sim p$, in spite of the superior's arguments that produce defeaters for $\sim p$. The egoist, however, refuses to assent to $p$ simply on the grounds that she herself did not witness the event in question.
} 


\section{References}

Alston, W. (2005). Beyond "justification": dimensions of epistemic evaluation. Ithaca, NY: Cornell University Press.

Aquinas, T. (198I). Summa theologica. trans. the Fathers of the English Dominican Province. Westminster, MD: Christian Classics.

Aquinas, T. (1993). Commentary on Aristotle's nicomachean ethics. trans. C. I. Litzinger. South Bend, IN: Dumb Ox Books.

Aquinas, T. (1994). Truth. trans. Robert W. Mulligan. Indianapolis, IN: Hackett Publishing.

Aquinas, T. (2005). Disputed questions on the virtues. E. M. Atkins and Thomas Williams, eds. New York: Cambridge University Press.

Aquinas, T. (2012). Corpus Thomisticum, S. Thomae de Aquino opera omnia. The University of Navarre. www.unav.es/filosofia/alarcon/amicis/ctopera.html\#OM. Accessed I3 November 2012.

Audi, R. (2006). Testimony, credulity, and veracity. The Epistemology of Testimony, Jennifer Lackey and Ernest Sosa, eds. New York: Oxford University Press.

Baehr, J. (2006). Character, reliability and virtue epistemology. The Philosophical Quarterly, Vol. 56, No. 223: 193-212.

Baehr, J. (2008). Four varieties of character-based virtue epistemology. The Southern Journal of Philosophy, 46 (2008): 469-502.

Bloomfield, P. (20II). Justice as a self-regarding virtue. Philosophy and Phenomenological Research, Vol. LXXXII No. I: 46-64.

Frances, B. (2010). The reflective epistemic renegade. Philosophy and Phenomenological Research, Vol. LXXXI, No. 2: 419-463.

Fricker, M. (2003). Epistemic injustice and a role for virtue in the politics of knowing. Metaphilosophy, 34: I54-I73.

Fricker, M. (2007). Epistemic injustice: power and the ethics of knowing. New York: Oxford University Press.

Greco, J. (1999). Agent reliabilism. Philosophical Perspectives, I3: Epistemology, ed. James Tomberlin. Atascadero, CA: Ridgeview Press.

Greco, J. (20IO). Achieving knowledge: a virtue-theoretic account of epistemic normativity. New York: Cambridge University Press.

Hibbs, T. (1999). Aquinas, virtue, and recent epistemology. The Review of Metaphysics, Vol. 52, Issue 3: 573-594.

Kawall, J. (2002). Other-regarding epistemic virtues. Ratio, Vol. XV: 257-275.

Lackey, J.(I999). Testimonial knowledge and transmission. The Philosophical Quarterly, Vol. 49, No. 197: 472-490.

Lackey, J. (2007). Why we don't deserve credit for everything we know. Synthese, I58:345-36I.

Lackey, J. (2009). Knowledge and credit. Philosophical Studies, I42:27-42.

Lepock, C. (20II). Unifying the intellectual virtues. Philosophy and Phenomenological Research, Vol. LXXXIII No. I: I06-I28.

Moros, E. R. and Umbers, R. J. (2004). Distinguishing virtues from faculties in virtue epistemology. The Southern Journal of Philosophy, Vol. XLII: 6I-85.

Riggs, W. (2009). Two problems of easy credit. Synthese, I69: 20I-2I6.

Roberts, R. C. and Wood, W. J. (2007). Intellectual virtues: an essay in regulative epistemology. New York: Oxford University Press.

Zagzebski, L. (1996). Virtues of the mind: an inquiry into the nature of virtue and the ethical foundations of knowledge. New York: Cambridge University Press. 
Zagzebski, L. (2007). Ethical and epistemic egoism and the ideal of autonomy. Episteme: a journal of social epistemology, Vol. 4, No. 3: 252-263.

Zagzebski, L. (20I2). Trust. http://www.ou.edu/ouphil/faculty/zagzebski/Trust.pdf. Accessed I3 November 2012. 